\title{
Industrial Relations in India in the Era of Liberalization
}

\author{
Rajni Pathania \\ Research Scholar Department of Business Economics The M.S. University Of Baroda Vadodara, \\ 390002 Gujarat, India.
}

\begin{abstract}
This paper examines the industrial relation in India in the Era of liberalization. The main focus of this study is trends in Intensity of industrial disputes, its causes and the growth of trade unions in India during the year 1992 to 2011.Results indicates that there is satisfactory industrial relation in India, due to the growth of trade union and continuous decline in industrial strikes and lockout during the entire study period.
\end{abstract}

Keywords: Liberalization, Trend, Intensity, Disputes, Trade Union, lockout.

\section{Introduction}

Industrial relations has become one of the most delicate and complex problems of modern industrial society. Industrial progress is not possible without collaboration of labors and harmonious relationships. The term industrial relations has a broad as well as a narrow outlook. Originally, industrial relations was broadly defined to include the relationships and interactions between employers and employees. From this perspective, industrial relations covers all aspects of the employment relationship, including human resource management, employee relations, and union-management relations. Now its meaning has become more specific and restricted. Accordingly, industrial relations pertains to the study and practice of collective bargaining, trade unionism, and labour-management relations, while human resource management is a separate, largely distinct field that deals with non-union employment relationships and the personnel practices and policies of employers.

\section{Review Of Literature}

In previous years, there has been a tendency to understand and interpret the problems of industrial relations in different environments and as a consequence various regional/area studies have emerged. A lot of studies have been done on the different aspects of Industrial relation at national and international level. A few studies have been taken for review:

Khurana (1972) analyzed the industrial relations in the private and the public sectors in India. The author makes a comparative study of the industrial relations in the two sectors on the basis of the criteria of industrial conflict, performance of the tripartite forums, implementation of the Code of Discipline, and several antecedent variables that have an important bearing on industrial relations. This study found that industrial relations in both the sectors have progressively deteriorated during 1962-1968, and that the public sector registered a better performance on the criterion of industrial conflict

Singh (1983): Examined the pattern of Industrial Relationships in Maharashtra and analyses the inevitability and universal. This study found that the pay allowances and Personnel Reasons are the dominant cause due to which strikes have been taking place.

Islam (1983) his study attempts to define industrial relations in greater depth and details in Bangladesh. It focused on the role of industrial relations in promoting or negating the overall economic growth of a country.

Gani (1990) examined the industrial relation in Jammu and Kashmir. The study found that the wages and allowances was the major causes behind the industrial disputes in the state. This study concludes that, both the direct and third party dispute settlement measures have, by and large, not been successful in the state.

Saha and Pan (1994) discussed the determinants of industrial disputes (both strikes and lock-outs) by developing an econometric model using disputes data for 19 industries over seven years from 1980 to 1986. It is found that in more unionised industries, man days lost from disputes are likely to be less compared to less unionised industries. In contrast, industries with larger average factory size will have greater man days lost. Employees' monthly earnings seem to be a weak variable having ambiguous and almost insignificant effects on man days lost.

No such comprehensive study has been undertaken so far in the National level during the era of Liberalisation. The present study attempts to fill this gap and make a modest contribution in this direction. In the pre liberalisation era labour was protected in labour market and capital in capital market. In post liberalisation era both labour and capital feels less protected. Indian employers feel that after globalisation instead of realizing the opportunities in the global markets, they are not able to compete even in domestic market. The present study attempts to examine the industrial relation in the era of liberalisation in India. 


\section{I.II Objectives of Study}

1. To examine the Trends in Intensity of Industrial disputes in India during 1992-2011.

2. To examine the main causes of industrial disputes in India.

3. To examine the growth of Trade union in India.

\section{Data collection and Methodology}

\section{II.I Data Source}

The data have been obtained from the year 1992 to 2011 for number of industrial disputes, workers involve man days lost and Number of registered trade union, from the various issues or reports of Indian Labour Statistics 1992-2011.

\section{Techniques}

Results have been computed with the help of following formulas:

Annual Growth Rate $=\quad($ New value - Old Value/ Old Value $) * 100$

Average Annual Growth Rate $=($ Annual growth rate in Period A + Annual growth rate in Period B .......Annual growth rate in Period n) / Total Number of Periods

Dispute Duration Ratio $=$ Man days Lost /Workers Involved

Dispute Coverage Ratio $=$ Workers Involved/Number of Disputes

Time Loss Ratio = Man days Lost/ Number of Disputes

\section{Analysis of Industrial Relation in India}

Table 1

Trends in Intensity of Industrial Disputes, 1992-2011

\begin{tabular}{|c|c|c|c|c|c|c|}
\hline Year & $\begin{array}{l}\text { Disputes } \\
\text { (D) }\end{array}$ & $\begin{array}{l}\text { Workers } \\
\text { Involved } \\
(W)\end{array}$ & $\begin{array}{c}\text { Mandays } \\
\text { Lost (000) } \\
\text { (L) }\end{array}$ & $\begin{array}{l}\text { Index Of } \\
\text { No. Of } \\
\text { Disputes } \\
\text { Base } \\
\text { 1993=100 }\end{array}$ & $\begin{array}{c}\text { Index Of No. } \\
\text { Worker } \\
\text { Involved } \\
\text { Base1993=100 }\end{array}$ & $\begin{array}{c}\text { Index Of } \\
\text { Mandays } \\
\text { Lost } \\
\text { Base } \\
\text { 1993=100 }\end{array}$ \\
\hline 1992 & 1714 & 1252225 & 31259 & 123.04 & 131.28 & 153.98 \\
\hline 1993 & 1393 & 953867 & 20301 & 100.00 & 100.00 & 100.00 \\
\hline 1994 & 1201 & 846429 & 20983 & 86.22 & 88.74 & 103.36 \\
\hline 1995 & 1066 & 989695 & 16290 & 76.53 & 103.76 & 80.24 \\
\hline 1996 & 1166 & 939304 & 20285 & 83.70 & 98.47 & 99.92 \\
\hline 1997 & 1305 & 981267 & 16971 & 93.68 & 102.87 & 83.60 \\
\hline 1998 & 1097 & 1288923 & 22062 & 78.75 & 135.13 & 108.67 \\
\hline 1999 & 927 & 1310695 & 26787 & 66.55 & 137.41 & 131.95 \\
\hline 2000 & 771 & 1418299 & 28763 & 55.35 & 148.69 & 141.68 \\
\hline 2001 & 674 & 687778 & 23767 & 48.38 & 72.10 & 117.07 \\
\hline 2002 & 579 & 1079434 & 26586 & 41.56 & 113.16 & 130.96 \\
\hline 2003 & 552 & 1815945 & 30256 & 39.63 & 190.38 & 149.04 \\
\hline 2004 & 477 & 2072221 & 23866 & 34.24 & 217.24 & 117.56 \\
\hline 2005 & 456 & 2913601 & 29665 & 32.74 & 305.45 & 146.13 \\
\hline 2006 & 430 & 1810348 & 20324 & 30.87 & 189.79 & 100.11 \\
\hline 2007 & 389 & 724574 & 27167 & 27.93 & 75.96 & 133.82 \\
\hline 2008 & 421 & 1579298 & 17434 & 30.22 & 165.57 & 85.88 \\
\hline 2009 & 392 & 1625505 & 13365 & 28.14 & 170.41 & 65.83 \\
\hline 2010 & 425 & 1059664 & 17912 & 30.51 & 111.09 & 88.23 \\
\hline 2011 & 91 & 48156 & 621 & 6.53 & 5.05 & 3.06 \\
\hline $\begin{array}{l}\text { Period } \\
\text { Average1992- } \\
2011\end{array}$ & 776.3 & 1269861 & 21733.2 & 55.72 & 133.12 & 107.05 \\
\hline
\end{tabular}

Source: Researcher's own calculation based on Indian Labour Statistics Data 1992-2011. 
During the last 20 years, on an average, about ten industrial disputes involving more than 1252225 workers and resulting in loss of more than 13,365 man days per year were reported in India (Table 1). In 1992, 1,714 total strikes and lockout were recorded. As a result, 31259 workdays were lost. More than 1252225 workers were involved in these labour disputes. The number and seriousness of strikes and lockouts have varied from year to year. As can be seen from the below chart, there has been a steep decline in the number of disputes in India. There were 91 labour disputes in 2011, resulting in the loss of 621 man-days, while the number of workers involved stood at 48156. Year 1992, recorded highest industrial dispute year and also recorded as highest man days lost year. Above table reveal that highest worker involved in disputes during the year 2005, i.e. 2913601 lakhs worker involved in 456 disputes, resulting more than 600 man-days lost. Year 2011 recorded as less strikes and lockouts, less man days lost, less worker involved in industrial disputes in India. This continuous decline in strikes and lockouts indicates that the industrial relations in India are improving.

III.I WORKERS' PARTICIPATION IN CONFLICTS For assessing the extent of workers' participation and involvement in industrial conflicts, three criteria have been adopted from Ross and Hartman (1960): (A) Dispute Duration Ratio, (b) Dispute Coverage Ratio, and (c) Time Loss Ratio. The data on these measures are summarised in Table 2.

III.II Disputes Duration Ratio: It is seen from Table 2 that an employee involved in disputes, generally remained off the job for a relatively shorter duration, averaging 1.90 days per year, during 1992-2011. However, there is evidence of an unsystematic behaviour. The average duration of the disputes varied from a low of 0.82 days to a high of 3.46 days. The main reason for the overall low dispute duration is the low sustaining power of the trade unions to withstand the pangs of strikes and lockouts, arising out of the loss of their earnings during the periods of strike activity.

III.IV Dispute Coverage Ratio: Taking the period under study, as a whole, about 2146 workers have been involved per conflict per year. The year-wise performance shows variable trend in the Dispute Coverage Ratio. However, the general upswing in die ratio is the probable result of two factors: (i) rapid growth in the number of relatively large sized firms involving large number of workers, and (ii) a considerable increase in the number of trade unions accompanied by a higher membership involvement

III.V Time Loss Ratio: Though, on an average, about 3374 man-days were lost per dispute during 1992-2011, no regular trend is witnessed. The ratio has ranged from as low as 682.42 in 2011 to as high as 6983.80 in 2007.

Table 2

Measures of Workers Participation in Conflicts, 1992-2011

\begin{tabular}{|c|c|c|c|}
\hline Year & Dispute Duration Ratio L/W & Coverage Ratio W/D & Time Loss Ratio L/D \\
\hline 1992 & 2.50 & 730.59 & 1823.75 \\
\hline 1993 & 2.13 & 684.76 & 1457.36 \\
\hline 1994 & 2.48 & 704.77 & 1747.13 \\
\hline 1995 & 1.65 & 928.42 & 1739.71 \\
\hline 1996 & 2.16 & 805.58 & 1300.46 \\
\hline 1997 & 1.73 & 751.93 & 2011.12 \\
\hline 1998 & 1.71 & 1174.95 & 2889.64 \\
\hline 1999 & 2.04 & 1413.91 & 3730.61 \\
\hline 2000 & 2.03 & 1839.56 & 3526.26 \\
\hline 2001 & 3.46 & 1020.44 & 4591.71 \\
\hline 2002 & 2.46 & 1864.31 & 5481.16 \\
\hline 2003 & 1.67 & 3289.76 & 5003.35 \\
\hline 2004 & 1.15 & 4344.28 & 6505.48 \\
\hline 2005 & 1.02 & 6389.48 & 4726.51 \\
\hline 2006 & 1.12 & 4210.11 & 6983.80 \\
\hline 2007 & 3.75 & 1862.66 & 4141.09 \\
\hline 2008 & 1.10 & 3751.30 & 3409.44 \\
\hline 2009 & 0.82 & 4146.70 & 4214.59 \\
\hline 2010 & 1.69 & 2493.33 & 682.42 \\
\hline 2011 & 1.29 & 529.19 & 3374.69 \\
\hline Period & 1.90 & 2146.80 & \\
\hline Average1992- & & & \\
\hline Sol1 & & & \\
\hline
\end{tabular}

Source: Researcher's own calculation based on Indian Labour Statistics Data 1992-2011. 
Industrial Relations In India In The Era Of Liberalization

Table 3

Percentage Distribution of Disputes By Causes

\begin{tabular}{|c|c|c|c|c|}
\hline Cause/ Year & $\mathbf{2 0 0 2}$ & $\mathbf{2 0 0 3}$ & $\mathbf{2 0 0 4}$ & $\mathbf{2 0 0 5}$ \\
\hline $\begin{array}{c}\text { Wages and } \\
\text { allowances }\end{array}$ & 21.3 & 20.4 & 26.2 & 21.8 \\
\hline Personnel & 14.1 & 11.2 & 13.2 & 9.6 \\
\hline Retrenchment & 2.2 & 2.4 & 0.2 & 0.4 \\
\hline Lay off & 0.4 & 0.6 & - & 0.2 \\
\hline Indiscipline, & 29.9 & 36.9 & 0.9 & 0.4 \\
\hline Violence & 0.9 & 1 & 0.4 & 3.6 \\
\hline $\begin{array}{c}\text { Leave and working } \\
\text { hours }\end{array}$ & 0.5 & 1 & 3.5 & 7.1 \\
\hline Bonus & 6.7 & 6.7 & 5.7 & 1.1 \\
\hline Charter of Demands & 10.5 & 8.8 & 0.7 & 0.2 \\
\hline Work load & 0.5 & 0.4 & 2.4 & \\
\hline Safety measures & 1.8 & 1 & & \\
\hline
\end{tabular}

Source: Indian Labour Statistics. 2002 - 2005.

III.VI Wages and allowances: Since the cost of living index is increasing, workers generally bargain for higher wages to meet the rising cost of living index and to increase their standards of living. In 2002, $21.4 \%$ of disputes were caused by demand of higher wages and allowances. This percentage was $20.4 \%$ during 2003 and during 2004 increased up to $26.2 \%$. In 2005, wages and allowances accounted for $21.8 \%$ of disputes.

III.VII Personnel and retrenchment: The personnel and retrenchment have also been an important factor which accounted for disputes. During the year 2002, disputes caused by personnel were $14.1 \%$ while those caused by retrenchment and layoffs were $2.2 \%$ and $0.4 \%$ respectively. In 2003 , a similar trend could be seen, wherein $11.2 \%$ of the disputes were caused by personnel, while $2.4 \%$ and $0.6 \%$ of disputes were caused by retrenchment and layoffs. In year 2005 , only $9.6 \%$ of the disputes were caused by personnel, and only $0.4 \%$ were caused by retrenchment

III.VIII Indiscipline and violence: From the given table, it is evident that the number of disputes caused by indiscipline has shown an increasing trend. In 2002, 29.9\% of disputes were caused because of indiscipline, which rose up to $36.9 \%$ in 2003. Similarly in 2004 and $2005,40.4 \%$ and $41.6 \%$ of disputes were caused due to indiscipline respectively. During the year 2003, indiscipline accounted for the highest percentage (36.9\%) of the total time-loss of all disputes, followed by cause-groups wage and allowance and personnel with $20.4 \%$ and11.2\% respectively. A similar trend was observed in 2004 where indiscipline accounted for $40.4 \%$ of disputes.

III.IX Bonus: Bonus has always been an important factor in industrial disputes. $6.7 \%$ of the disputes were because of bonus in 2002 and 2003 as compared to 3.5\% and 3.6\% in 2004 and 2005 respectively.

III.X Leave and working hours: Leaves and working hours have not been so important causes of industrial disputes. During 2002, $0.5 \%$ of the disputes were because of leave and hours of work while this percentage increased to $1 \%$ in 2003. During 2004, only $0.4 \%$ of the disputes were because of leaves and working hours.

Table 4

Growth of Trade Unions and Their Membership in India

\begin{tabular}{|c|c|c|c|}
\hline Year & $\begin{array}{l}\text { Number of Register } \\
\text { Trade union }\end{array}$ & $\begin{array}{l}\text { Membership of the union } \\
\text { Submitting Returns ( 000) }\end{array}$ & $\begin{array}{l}\text { Yearly Growth Rate } \\
\text { of Trade Unions }\end{array}$ \\
\hline 1992 & 55680 & 5746 & - \\
\hline 1993 & 55784 & 3134 & 0.19 \\
\hline 1994 & 56872 & 4094 & 1.95 \\
\hline 1995 & 57952 & 6538 & 1.90 \\
\hline 1996 & 58988 & 5601 & 2.79 \\
\hline 1997 & 60660 & 7409 & 2.58 \\
\hline 1998 & 62223 & 7249 & 4.17 \\
\hline 1999 & 64817 & 6407 & 1.91 \\
\hline 2000 & 66056 & 5420 & 0.86 \\
\hline
\end{tabular}


Industrial Relations In India In The Era Of Liberalization

\begin{tabular}{|c|c|c|c|}
\hline 2002 & 68544 & 6973 & 2.88 \\
\hline 2003 & 74649 & 6277 & 8.91 \\
\hline 2004 & 74403 & 3397 & -0.33 \\
\hline 2005 & 78465 & 8722 & 5.46 \\
\hline 2006 & 88440 & 8960 & 12.71 \\
\hline 2007 & 95783 & 7877 & 8.30 \\
\hline \multicolumn{3}{|l}{} \\
\hline
\end{tabular}

Source: Indian Labour Statistics. 1992 - 2007.

The above table gives idea of the growth of the trade union in India. The growth of trade union in the year 1992- 2007 has been phenomenal; the number of registered union increased in entire study period. The annual growth rate of trade union recorded highest during 2006 i.e. $12.71 \%$ and lowest in 2004 i.e. $-0.33 \%$. The number of registered union increased from 55680 with a total membership of 5746 lakhs in 1992 to 95783 with total membership of 7877 lakhs in 2007-08. The average annual growth rate of registered trade union was $3.51 \%$. This increase has been brought about by a variety of factors such as changed outlook towards labour organisation, a new spirit of awakening in the country etc.

\section{Conclusion, Limitations and Suggestions}

\section{IV.I Conclusion}

The analysis of the situation of industrial relation in India revealed that :

$>$ The year 1992 was the most disturbed year, registering maximum number of strikes and lockouts, with maximum number of man days lost.

$>$ The year 2011 faced the minimum number of strikes and lockouts with the least number of man days lost and minimum workers involved.

$>$ Cause wise distribution of industrial disputes during the year 2002 to 2005 has been shown that demand for higher wages has been the dominant cause for the industrial disputes.

$>$ The growth of trade union during the 1992- 2007 has been extraordinary; the number of registered union improved in entire study period.

$>$ The continuous decline in strikes and lockouts and extraordinary growth of trade union indicates that the industrial relations in India are improving.

\section{IV.II Limitation of the study:}

The limited database, short time period and selected variables are some of the major limitations of this study. However in future research scholars or students can work on more variables which will provide better experience to the students for their bright career.

\section{IV.III Suggestions}

1) The participation of workers in the management of the industrial unit should be encouraged by making effective use of works committees, joint consultation and other methods.

2) The employers must recognize the right of collective bargaining of the trade unions.

3) The management should sincerely implement the settlements reached with the trade unions.

To conclude, we can say that industrial relations in India are governed by certain forces- economic, social and political. Industrial relations can change for the better only if there is a convincing change in the attitudes of employers and employees and they both take responsible and realistic interest in their mutual goals and requirements. The Government should play an active role for promoting industrial peace. It should make law for the compulsory recognition of a representative union in each industrial unit. It should intervene to settle disputes if the management and the workers are unable to settle their disputes. This will restore industrial harmony.

\section{References}

[1] S. Khurana, Industrial Relations in Private and Public Sector Industry in India: A Comparative Analysis, Indian Journal of Industrial Relations, 7(3), January- 1972,411-431.

[2] M. Singh, Industrial Relations in Maharashtra, Indian Journal of Industrial Relations, 18(4), April-1983, 549-567.

[3] M. Islam, Industrial Relations in Bangladesh, Indian Journal of Industrial Relations, 19(2), October- 1983,161-189.

[4] Gani, Industrial Relations in Jammu and Kashmir, Indian Journal of Industrial Relations, 26(1), July-1990, 53-67

[5] Saha and I. Pan, Industrial Disputes in India: An Empirical Analysis, Economic and Political Weekly, 29(18), April-1994, 10811087 